\title{
Tribute to David Swinney
}

\author{
Edward E. Smith
}

Published online: 28 March 2009

(C) Springer Science+Business Media, LLC 2009

I met David in Cambridge, MA, around 1980. We were introduced by Edgar Zurif. It was apparent early on that David and I shared two passions, the study of Cognition, and the joy of running. David and I ran together everywhere, from Fresh Pond in Cambridge to Central Park (during his CUNY years), to the backwoods of Ann Arbor (during my Michigan years), to the beachfront walkway in La Jolla. We usually talked shop on our runs, and there was an idea for an experiment that we came up with at a particular spot on our Fresh Pond run, that we could never remember when we stopped, but that would come back to us when we hit that spot again. (We both knew about state-dependent memory.) Intellectually, what appealed to me greatly about David was that he was as much a cognitive psychologist as a psycholinguist. I liked the way he approached problems in language from a cognitive perspective, and was awed by his phenomenal attention to getting all the experimental details right. He was one of the best methodologists I have ever seen, and he was creative at the same time. From the day we met we talked a lot of psychology. We collaborated on a number of projects together, shared a grant, published some papers together (ironically, mostly in David's last year), but alas, our joint work often was not always on the top-of-the-pile for either of us. Still, the work and the running led to one of the deepest friendships I have had in my adult life. He was one of the warmest and accepting men I have ever met, and like others in his inner circle, I treasured him.

E. E. Smith $(\varangle)$

Department of Psychology, Columbia University, New York, USA

e-mail: eesmith@psych.columbia.edu 